\title{
Key Vulnerabilities and Limitations in the Management of Hazardous Waste and Its Disposal: A Checklist Assessment Tool
}

\author{
Rob White, Diane Heckenberg \\ School of Sociology and Social Work, University of Tasmania, Hobart, Australia. \\ Email: R.D.White@utas.edu.au \\ Received September $9^{\text {th }}, 2011$; revised October $6^{\text {th }}, 2011$; accepted November $5^{\text {th }}, 2011$.
}

\begin{abstract}
From an environmental protection perspective, the crucial issues pertaining to the policing of hazardous waste relate to both the vulnerabilities and limitations of current practices, and the potential issues that demand attention in the here and now, to alleviate future calamity. This paper describes the process involved in developing a vulnerabilities and limitations checklist that provides a relatively simple yet multi-pronged approach to assessing present and future environmental harms and crimes within the hazardous waste sector. Although it was not the intention of the authors to develop a generic checklist, this tool may prove useful to other industry sectors.
\end{abstract}

Keywords: Hazardous Waste, Vulnerabilities Checklist, Environmental Crime

\section{Introduction}

From a criminal justice perspective, environmental protection is intimately linked to issues pertaining to crime, criminality and the potential to do harm. The waste management area presents numerous opportunities for crime [1]. This is acknowledged by the illegitimate international trade and transportation of hazardous wastes [2], the role of organized criminal syndicates in waste management [3], and the illegal dumping of waste by legitimate corporations $[4,5]$.

The very nature of the industry - getting rid of sometimes dangerous substances at a competitive price clearly opens up the prospect of wrongdoing [5].

What is meant by hazardous waste, and the links between disposal of hazardous waste and specifically criminal activity, warrants closer scrutiny. Certainly from a criminological perspective, there is little knowledge of the scale of the problem in Australia, the types of criminality involved, or the precise nature of disposal (e.g., illegal dumping, combining illegal with legal waste, illegal export). Aside from an investigation by the Australian Crime Commission (unpublished) and a recently released report by the Australian Institute of Criminology [6] few police investigators or academic researchers have examined the policing of hazardous waste disposal in the Australian context.
Findings by Bricknell [6] are consistent with the international literature that indicates that there is a relationship between hazardous waste disposal and organized crime.

Waste disposal management has been infiltrated overseas by organized criminals and the business of dumping waste in Australia is not immune to similar penetration. The available evidence for an association with organized crime is presently anecdotal and specifics are lacking. However, the structure of the system, the ease in which waste can be transferred and the apparent formation of alliances between operators already working on the fringes of legal activity, makes it one of the likelier candidates for organized criminal activity (AIC Roundtable participant's personal communications 2009, cited in [6].

In 2001, the Independent Commission Against Corruption (ICAC) [7] conducted a strategic assessment of the New South Wales waste sector to identify the associated corruption risks. The assessment identified a number of issues and corruption-related risks that needed to be addressed, for the following reasons:

- there is a history, internationally, of unscrupulous operators, behaviour has included threats and intimidation. Locally, there have been a number of cases of corrupt conduct in the industry [7].

- many different organisations are involved in the in- 
dustry ranging from small one-person operations to transnational companies [7].

- the industry as a whole lacks a cohesive structure and tends to be ad hoc in focus and management [7].

The assessment also found that 'the waste sector exhibits a number of what ICAC termed "higher risk functions" including:

- Government's role in the waste sector beyond establishing the statutory framework involves public officials regulating the industry by monitoring compliance with planning and environmental protection legislation (corruption risk: regulatory activity) [7].

- Local councils are involved in supplying an essential service, waste collection, where demand can only be met by entering large and long-term collection contracts (corruption risk: allocation of scarce resource) [7].

- State and local government are involved in multimillion dollar contracts with the private sector to manage the collection, transportation and processing of waste (corruption risk: contracting) [7].

- Significant amounts of business on waste transfer and waste disposal facilities are conducted for cash (corruption risk: cash handling) [7].

Over the past few years, the ICAC has worked on many cases of corruption or potential corruption in various aspects of the waste sector. The allegations they have received often refer to favouritism when tendering or contracting for waste management services. Other common allegations include:

- misuse or theft of public resources,

- failure to make or keep proper records,

- fraudulently altering records (such as the tare weight for trucks entering and leaving tip sites), and

- bribery and collusion between interested parties [7].

\section{Our Study}

Comments by participants in our study of the hazardous waste sector in Australia acknowledge the sector's vulnerability and demonstrate awareness of the largely anecdotal evidence of organised crime in the sector, as well as the characteristics of perpetrators generally associated with the industry

When you put it all together the industry is open to exploitation - if you want to do it you can, if you do get caught you are going to get away with it (Participant, National Study)

The rumour-mill suggests there is organized crime (Participant, National Study)

There are organized individuals rather than organized crime - that is organized in their behavior - exploiting the industry (Participant, National Study)
The United Kingdom Serious Organised Crime Agency (SOCA) [8] describes the types of perpetrators and diverse relationships that characterise organised crime and organised criminal activities.

- Organised crime is defined as "those involved, normally working with others, in continuing serious criminal activities for substantial profit, whether based in the UK or elsewhere". Organised criminals that work together for the duration of a particular criminal activity or activities are what we call an organised crime group [8].

- Organised crime group structures vary. Successful organised crime groups often consist of a durable core of key individuals. Around them, there's a cluster of subordinates, specialists, and other more transient members, plus an extended network of disposable associates [8].

- Many groups are in practice loose networks of criminals that come together for the duration of a criminal activity, acting in different roles depending on their skills and expertise. Collaboration is reinforced by shared experiences (such as prison), or recommendation from trusted individuals. Others are bonded by family or ethnic ties - some "crime families" are precisely that [8].

- Organised criminals make use of specialists who provide a service, sometimes to a range of crime gangs. Services include transport, money laundering, debt enforcement, or the provision of false documentation (identity crime underpins a wide variety of organised criminal activities) [8].

In addition, secondary, but no less serious crimes occur in conjunction with organized crime and waste disposal, such as the falsification of documentation and the clandestine processing of profits. This is illustrated in the following observation:

Money laundering is also rife among European criminal organisations involved in waste disposal and wildlife trafficking. The nature of these crimes implies a level of organised criminal contribution and, in some instances, there is. Hayman and Brack's (2002:7) analysis, however, suggests that the majority of environmental crime is perpetrated by "loosely organised networks of individuals with some specialist knowledge". These networks can still be intricately woven, particularly the chain(s) of connection between the middle-men or suppliers [6].

As an initial example of why all of this is important Vander Beken and Balcaen [9] illustrate in Table 1 the key opportunities for crime in the waste cycle.

Drawing on this type of background information and informed more specifically by the European literature on waste management, we began building a picture of the 
Table 1. Risks in the Waste Cycle.

\begin{tabular}{|c|c|}
\hline Illegal storage & $\begin{array}{l}\text { In cases where an empty hangar is found filled } \\
\text { with tyres or some other waste product with no } \\
\text { trace of the owner of the hangar, the work of a } \\
\text { crime group is suspected }\end{array}$ \\
\hline $\begin{array}{l}\text { Transboundary } \\
\text { shipment/trafficking } \\
\text { in toxic waste }\end{array}$ & $\begin{array}{l}\text { Waste cycle is vulnerable to trafficking at } 3 \\
\text { different stages: } \\
\text { 1) Initial transfer-from producer to firm } \\
\text { specialising in waste management } \\
\text { 2) Transit phase-transport and storage } \\
\text { activities can be run illegally, inspection of } \\
\text { storage sites may be sporadic } \\
\text { 3) Destination stage-treatment, recycling and } \\
\text { final disposal-illicit practices mean the waste } \\
\text { ends up elsewhere }\end{array}$ \\
\hline $\begin{array}{l}\text { Illegal dumping of } \\
\text { domestic, municipal } \\
\text { and industrial wastes }\end{array}$ & $\begin{array}{l}\text { Criminal groups take payment for disposal of } \\
\text { the waste but dump it illegally }\end{array}$ \\
\hline $\begin{array}{l}\text { Illegal dumping of } \\
\text { hazardous waste }\end{array}$ & $\begin{array}{l}\text { Illegal dumping of hazardous waste is an } \\
\text { activity in which the involvement of crime } \\
\text { groups can be identified }\end{array}$ \\
\hline
\end{tabular}

Source: Vander Beken and Balcaen (2006, pp. 304-305) [9].

overall vulnerability of the sector. This was achieved by gradually layering on top of the available overseas information, relevant observations from reports at State and Local level within Australia. We then added preliminary information from our present study (2011), gathered during informal discussions with participants from the states of Queensland, Tasmania, Victoria and Canberra.

\section{Four Perspectives}

Four geographical perspectives were considered in developing the vulnerabilities and limitations checklist tool for the management of hazardous waste. Presented below, these four perspectives are based upon the following sources of information and insight.

1) International/Regional

Informed by the European literature on the vulnerability and regulation of the hazardous waste sector $[1,9,10]$.

2) State

Informed by two key reports - the 2010 Victorian Auditor-General's report on a State Regulator [11] and the Ombudsman Victoria's 2010 report on a municipal landfill [12].

3) Local

Informed by the 2002 Independent Commission Against Corruption report [7] report on a Municipal operator/ regulator.

4) National

Informed by findings from preliminary discussions with a representative of the Australian Crime Commission and 17 participants from Canberra, Brisbane, Melbourne and Hobart involved in regulating hazardous waste disposal in Australia at international, national and state levels.

The information gathered above, together with litera- ture and reports on organized crime and waste-specific crimes, informs the list of limitations and vulnerabilities presented in this paper. Our idea was to develop a tool to assess overall environmental regulatory performance specifically in relation to the management of hazardous waste and its disposal, although the list may be useful for other assessment purposes pertaining to environmental protection as well.

The development process began with exploring definitions of organized crime, the nature of organized criminal groups, key motivations for organized criminals to infiltrate companies, the characteristics of organizations that are vulnerable to infiltration [6,8,13-21], the modus operandi of crime and criminals in other domains such as the black market in tiger products in China [13]; issues surrounding the global movement of electronic waste [22] and issues related to corruption [7,23].

Drawing from the European literature on the vulnerability of the hazardous waste sector to organized crime as well as the risks inherent in the waste cycle $[1,9,10]$ we formulated a preliminary list of ten key vulnerabilities. A 2007 study [5], for instance, notes various vulnerabilities, such as "the conflict between economic and environmental interests which creates incentive for illegal profit maximization"; "a corporate culture that considers protection of the environment to be less important than profits" [5] "the considerable savings to be made by illegal disposal" [5]; unfair competition and declining prices which act as deterrents to new [legitimate] market entrants, as well as a market that becomes unattractive to new entrepreneurs because of its bad reputation [5].

This literature provided the first ten vulnerabilities.

1) Economics versus ecology;

2) Nature and value of waste;

3) Legislative ambiguity;

4) Complex regulatory environment;

5) Regulatory capture;

6) Waste classification;

7) Compliance rather than enforcement;

8) Systems and processes;

9) Risks in the waste cycle;

10) Prosecution, sentencing and greening of the judiciary;

The focus then turned to Australia and a 2010 Victorian Auditor General's Report [11] on a State Environmental Protection Agency, and the 2010 Ombudsman Victoria's Report [12] on a state municipal landfill, which added two further vulnerabilities:

11) Information management;

12) Governance;

A review of the 2002 Independent Commission Against Corruption Report [7] concerning corruption risks at lo- 
cal municipal level, in particular the "corruption risks in a nutshell" (which includes attributes such as: attitude towards waste, nature of the waste sector, value of waste, complex regulatory environment, conflicting roles of government, risk and regulatory functions, waste classification, new technology and new markets, grants administration, tendering for waste services, contract administration and audit, dealing with poor contractor performance, public sector values and business ethics, threats to regulators, detecting illegally dumped waste, cash handling at facilities and bypassing weighbridge procedures) reaffirmed the above 12 vulnerabilities and contributed a further two:

13) Conflicts of interest;

14) Monitoring contractor performance;

Finally, the thematic coding of preliminary findings from informal discussions with the participants in our study — against the 14 indicators above — added a further four vulnerabilities.

15) Investigatory capacity and expertise;

16) Resources;

17) Collaboration;

18) Politicization.

At this point it became clear that several of the indicators could more accurately be described as limitations (drawbacks) rather than vulnerabilities (exposure). From there it was a matter of systematically examining and refining the definitions for each indicator. These $18 \mathrm{vu}-$ lnerabilities and limitations are defined in Table 2. In turn, the 18 indicators can be utilized as an organizational diagnostic tool—namely a checklist—for rapid assessment of vulnerabilities and limitations in a particular jurisdiction, as illustrated in Table 3.

\section{Looking to the Future}

The checklist tool presented above can be used to evaluate existing regulatory practices. It would also be of value at some stage to further develop the ideas implicit within this assessment tool into an integrated theoretical model. Similarly, the tool could be coupled with horizon scanning for the purposes of forward planning [26].

For example, the use and need for horizon scanning as an intellectual exercise and planning tool is related to the idea that 'many threats and opportunities are presently poorly recognized' [24]. Accordingly a more systematic approach to identification nd solution of issues is required, rather than reliance upon ad hoc or reactive approaches. For example, "the need for horizon scanning of environmental issues is illustrated by the recent failure to foresee both the widespread adoption of the range of bio-fuels currently in use, and the environmental consequences of bio-fuels production" [25]. Horizon scanning can provide insight into risks (potential problems) and harms (actual problems). Coupled with concepts such as paradoxical harm (refers to apparently contradictory yet consciously chosen forms of harm), and the mobility of harm (transference), horizon scanning provides a mechanism to discern where emerging threats (and positive opportunities) may arise and potential strategies for mitigating or adapting to these [26].

One emerging issue on a global scale is industrial

Table 2. Key Vulnerabilities \& Limitations.

\begin{tabular}{|c|c|}
\hline $\begin{array}{l}\text { Economics } \\
\text { versus } \\
\text { ecology }\end{array}$ & $\begin{array}{l}\text { Conflict between economic and environmental } \\
\text { interests creates incentives for illegal profit } \\
\text { maximization }\end{array}$ \\
\hline $\begin{array}{l}\text { Characteristics } \\
\text { of waste }\end{array}$ & $\begin{array}{l}\text { Crime risks vary according to the type of } \\
\text { product }\end{array}$ \\
\hline $\begin{array}{l}\text { Legislative } \\
\text { definitions }\end{array}$ & $\begin{array}{l}\text { New definitions of waste that open up } \\
\text { opportunities for crime }\end{array}$ \\
\hline $\begin{array}{l}\text { Complex } \\
\text { Regulatory } \\
\text { Environment }\end{array}$ & Conditions under which regulation takes place \\
\hline $\begin{array}{l}\text { Regulatory } \\
\text { Capture }\end{array}$ & Regulators compromised by those they regulate \\
\hline $\begin{array}{l}\text { Waste } \\
\text { Classification }\end{array}$ & Ambiguity as to which wastes are hazardous \\
\hline $\begin{array}{l}\text { Compliance } \\
\text { rather than } \\
\text { enforcement }\end{array}$ & $\begin{array}{l}\text { Administrative controls focused on licensing } \\
\text { and site inspections, rather than enforcement }\end{array}$ \\
\hline $\begin{array}{l}\text { Simplification } \\
\text { of procedures }\end{array}$ & $\begin{array}{l}\text { Procedural changes, including simplification } \\
\text { and streamlining that create opportunities for } \\
\text { illegal activities }\end{array}$ \\
\hline $\begin{array}{l}\text { Risks inherent } \\
\text { in the Waste } \\
\text { Cycle }\end{array}$ & Vulnerability to illegality and illegal dumping \\
\hline $\begin{array}{l}\text { Prosecution \& } \\
\text { Sentencing }\end{array}$ & Environmental crime is not "real crime" \\
\hline $\begin{array}{l}\text { Information } \\
\text { Management }\end{array}$ & $\begin{array}{l}\text { All the systems and processes for the creation, } \\
\text { distribution, use, storage and retrieval of } \\
\text { information }\end{array}$ \\
\hline Governance & $\begin{array}{l}\text { Effective and efficient management practices } \\
\text { and general processes of ethical governance }\end{array}$ \\
\hline $\begin{array}{l}\text { Conflicts of } \\
\text { Interest }\end{array}$ & $\begin{array}{l}\text { Pressures on organizational unit to perform } \\
\text { multiple roles and attempt to service various } \\
\text { constituencies at the same time }\end{array}$ \\
\hline $\begin{array}{l}\text { Monitoring } \\
\text { Contractor } \\
\text { Performance }\end{array}$ & $\begin{array}{l}\text { Ongoing monitoring and assessment of } \\
\text { performance over time and relative to regulatory } \\
\text { frameworks }\end{array}$ \\
\hline $\begin{array}{l}\text { Investigatory } \\
\text { Capacity and } \\
\text { Expertise }\end{array}$ & $\begin{array}{l}\text { Considerable variation in pre-service and } \\
\text { in-service training, and in use of coercive and } \\
\text { investigatory powers }\end{array}$ \\
\hline Resources & $\begin{array}{l}\text { Inadequate funding and personnel to meet } \\
\text { current regulatory challenges }\end{array}$ \\
\hline Collaboration & $\begin{array}{l}\text { Nature of partnerships and partnership practices } \\
\text { both in terms of horizontal (across diverse } \\
\text { agencies and occupational spheres) and vertical } \\
\text { (top-bottom interaction) collaboration }\end{array}$ \\
\hline Politicization & $\begin{array}{l}\text { Influence of powerful sectional interests on } \\
\text { regulatory processes and outcome }\end{array}$ \\
\hline
\end{tabular}


Table 3. Synopsis of Vulnerabilities and Limitations.

\begin{tabular}{|c|c|c|c|}
\hline & Criteria & Example & $\begin{array}{l}\text { Check List } \\
\sqrt{ } / \mathrm{X}\end{array}$ \\
\hline 1 & Economics versus ecology & Significant cost savings to be made by dumping waste illegally & \\
\hline 2 & Characteristics of waste & Inelastic price - increase in price does not equally reduce demand for service & \\
\hline 3 & Legislative definitions & $\begin{array}{l}\text { Ambiguity about which wastes are hazardous and therefore subject to } \\
\text { legislation (e.g., depleted uranium }\end{array}$ & \\
\hline 4 & Complex regulatory environment & $\begin{array}{l}\text { Regulatory loopholes - poor regulation of waste brokers, absence of appropriate } \\
\text { regulations, quality of regulation }\end{array}$ & \\
\hline 5 & Regulatory capture & $\begin{array}{l}\text { Close working relationships between regulator and specific industries and } \\
\text { companies, including government }\end{array}$ & \\
\hline 6 & Waste Classification & Questions over who regulates which wastes & \\
\hline 7 & Compliance rather than enforcement & $\begin{array}{l}\text { Quality and quantity of enforcement highly variable and tendency is toward 'soft' } \\
\text { rather than "hard" end of compliance-enforcement continuum }\end{array}$ & \\
\hline 8 & Simplification of procedures & $\begin{array}{l}\text { Simplification of a procedure to recover hazardous waste can result in a } \\
\text { decrease in oversight, providing opportunity for crime }\end{array}$ & \\
\hline 9 & Risks inherent in the waste cycle & $\begin{array}{l}\text { Vulnerability of the waste cycle to trafficking at transfer, transit and destination } \\
\text { phases }\end{array}$ & \\
\hline 10 & Prosecution and Sentencing & Courts may not place great "value" on the nature of the offence & \\
\hline 11 & Information Management & $\begin{array}{l}\text { Proliferation of disparate information systems with little integration, poor record } \\
\text { keeping }\end{array}$ & \\
\hline 12 & Governance & $\begin{array}{l}\text { Failure to record the rationale for decisions taken at senior management level } \\
\text { regarding enforcement review matters }\end{array}$ & \\
\hline 13 & Conflicts of Interest & $\begin{array}{l}\text { Municipal body that has mandate to both dispose of waste and to regulate waste } \\
\text { disposal }\end{array}$ & \\
\hline 14 & Monitoring contractor performance & $\begin{array}{l}\text { Need for a strong audit culture to minimize any risks associated with poor } \\
\text { contractor performance }\end{array}$ & \\
\hline 15 & Investigatory capacity and expertise & $\begin{array}{l}\text { Variations in approaches to investigatory training and capacity building across } \\
\text { different jurisdictions }\end{array}$ & \\
\hline 17 & Collaboration & Poor vertical and horizontal collaboration & \\
\hline 18 & Politicization & $\begin{array}{l}\text { Interference in normal regulatory process by elected officials in favour of } \\
\text { specific business interests }\end{array}$ & \\
\hline
\end{tabular}

$\sqrt{ }=$ evidence of vulnerability or limitation in this jurisdiction; $X=$ no evidence of vulnerability or limitation in this jurisdiction.

Table 4. Case examples of stockpiling in Australia.

\begin{tabular}{|c|c|}
\hline Abattoir waste & $\begin{array}{l}\text { Wodonga Rendering fined } \$ 5841 \text { for stockpiling } 4000 \text { tonnes of rotting abattoir waste at a Carroll's Lane } \\
\text { property on the outskirts of the city [27]. }\end{array}$ \\
\hline POPs waste & $\begin{array}{l}\text { "What people don't realise is that there is a burgeoning stockpile of POPs waste in Australia and no treat- } \\
\text { ment capacity," [28]. }\end{array}$ \\
\hline HCB's & $\begin{array}{l}\text { Orica's (previously ICI) toxic stockpile of HCB's allowed to accumulate. (eg 60,000 barrels+) - Proposed } \\
\text { destination for disposal, Denmark- currently being contested in Denmark [29]. }\end{array}$ \\
\hline Radioactive waste & $\begin{array}{l}\text { Australia has total holdings of around } 4300 \text { cubic metres of radioactive waste. Sources include radioactive } \\
\text { medical, scientific and industrial waste; spent nuclear fuel from Australia's reactor at Lucas Heights near } \\
\text { Sydney and site contamination from British nuclear weapons tests conducted in South Australia in the } \\
1950 \text { s [30]. }\end{array}$ \\
\hline Tyres & $\begin{array}{l}\text { It is estimated that around } 18 \text { million waste tyres (measured in equivalent passenger units) are generated in } \\
\text { Australia each year. The disposal or re-use of waste tyres varies greatly between States and Territories but } \\
\text { overall nationally, it is estimated that about } 57 \% \text { of waste tyres go to landfill and } 13 \% \text { are disposed of inap- } \\
\text { propriately through illegal dumping [31]. }\end{array}$ \\
\hline Drycleaning waste & $\begin{array}{l}\text { The Fremantle Steam Laundry in Hamilton Hill burst into flames in the early hours of May } 13 \text {. Fire fighters } \\
\text { ordered some nearby residents to evacuate because the factory had a stockpile of the dry cleaning chemical } \\
\text { perchloroethylene (PCE) [32]. }\end{array}$ \\
\hline E-waste & Australia has a stockpile of toxic e-waste totalling well over 123 million items [33]. \\
\hline
\end{tabular}


stock piles. For example, in early October 2010, a thick red torrent of sludge burst from a reservoir at a metals plant 100 kilometres south of Budapest. At least seven people died as a result of the sludge surge, some went missing and over one hundred persons were physically injured as the toxic substance flowed into nearby villages and towns. The toxic sludge reached the Danube River several days later, from where it could flow into six other European countries before reaching the Black Sea: Croatia, Serbia, Romania, Bulgaria, Ukraine and Moldova. An ecological and social disaster for Hungary thus simultaneously poses an environmental threat to surrounding countries, and the human inhabitants, ecosystems and animal life of these.

This issue of stockpiling and its potential consequences also emerged as a key issue in our study of the policing of the disposal of hazardous waste in Australia. As such, it constitutes a specific area of vulnerability that requires further ongoing investigation vis-à-vis issues pertaining to the storage and disposal of hazardous materials. From the point of view of stockpiling, an important concern is the mobility and transferability (via air, water, soil and through cross-border pollution) of toxic substances. In our study, in relation to stockpiling, we received comments such as the following:

- Stockpiling is an issue;

- Lots of e-waste still goes to landfill;

- Mining tailings;

- Agricultural chemicals;

- Lead acid batteries;

- Spent acid wastes from galvanizing;

- Legacy wastes from sewage treatment plants;

- Fertilizers, soil conditioners;

- What they can stockpile is governed by the conditions of their license;

- For us to remove and dispose of them [stockpiled tyres] would cost in the vicinity of $\$ 375,000$ - the generator declares bankruptcy; they obtain the commercial advantage and the state pays.

There are certainly issues here that warrant much more consideration than is presently being given to these matters.

\section{Conclusions}

This paper provides a checklist that can be used as a tool to identify key vulnerabilities and limitations in the management of hazardous waste and its disposal. From an environmental protection perspective, the crucial issues pertaining to the policing of hazardous waste relate to both the vulnerabilities and limitations of current practices, and the potential problems that demand attention in the here and now to alleviate future calamity. Using this vulnerabilities and limitations checklist provides a relatively simple yet multi-pronged approach to assessing present and future environmental harms and crimes, within the context of the dynamics, dimensions and discourses of a particular industry and jurisdictional domain.

\section{REFERENCES}

[1] S. Van Daele, T. Vander Beken and N. Dorn, "The European Waste Disposal Sector," In: T. Vander Beken Ed., The European Waste Industry and Crime Vulnerabilities, Maklu Publishers, Antwerp-Apeldoorn, 2007, pp. 17-142.

[2] J. Clapp, "Seeping Through the Regulatory Cracks," SAIS Review, Vol. XXII, No. 1, 2002, pp. 141-155. doi:10.1353/sais.2002.0004

[3] D. Pellow, "The Politics of Illegal Dumping: An Environmental Justice Framework," Qualitative Sociology, Vol. 27, No. 4, 2004, pp. 511-525. doi:10.1023/B:QUAS.0000049245.55208.4b

[4] T. Carter, (1999) "Ascent of the Corporate Model in Environmental-Organized Crime," Crime Law and Social Change, Vol. 31, No. 1, 1991, pp. 1-25

[5] N. Dorn, S. Van Daele and T. Vander Beken, "Reducing Vulnerabilities to Crime of the European Waste Management Industry: The Research Base and the Prospects for Policy," European Journal of Crime, Criminal Law and Criminal Justice, Vol. 15, No. 1, 2007, pp. 23-36. doi:10.1163/092895607X193524

[6] S. Bricknell, "Environmental Crime in Australia," AIC Research and Public Policy Series, Australian Institute of Criminology, Canberra, 2010, p. 109, Accessed December 2010 .

http:/www.aic.gov.au/documents/2/1/1/\%7B211B5EB9E888-4D26-AED4-1D4E76646E4B\%7Drpp109.pdf

[7] Independent Commission against Corruption, "Taking the Whiff out of Waste: Guidelines for Managing Corruption Risks in the Waste Sector," November 2002.

[8] Serious Organised Crime Agency, "Serious Organised Crime Agency Organised Crime Groups: Threats, 20092010," United Kingdom, Accessed on 17 January 2011. http://www.soca.gov.uk/threats/organised-crime-groups

[9] T. Vander Beken and A. Balcaen, "Crime Opportunities Provided by Legislation in Market Sectors: Mobile Phones, Waste Disposal, Banking, Pharmaceuticals," European Journal of Criminal Policy Research, Vol. 12, 2006, pp. 299-323.

[10] T. Vander Beken (Ed.), "The European Waste Industry and Crime Vulnerabilities," Institute for International Research on Criminal Policy, Ghent University, 2007.

[11] Victorian Auditor General's Report, "Hazardous Waste Management," VAGR 2010, June 2010, Accessed August 2010. http://download.audit.vic.gov.au/files/09062010_Haz_W aste_Full_Report.pdf 
[12] Ombudsman Victoria, "Brookland Greens Estate-Investigation into Methane Gas Leaks," October 2009, Victorian Government Printer, Accessed August 2010.

http://www.ombudsman.vic.gov.au/resources/documents/ Brookland_Greens_Estate1.pdf

[13] J. Gosling, "A Response to the Global Crime Article, The Black Market in China for Tiger Products' (Brendan Moyle), Addressing Enforcement Related Assertions," 2009, Accessed March 2010. http://www.eia-international.org/files/news571-1.pdf

[14] F. G. Shanty and P. P. Mishra (Eds.), "Organized Crime: From Trafficking to Terrorism," An International Encyclopedia, California, ABC-CLIO Inc., Vol. 1, 2008.

[15] C. Hartfield, "Paradigms, Pathologies, and Practicalities Policing Organized Crime in England and Wales," Policing, Vol. 2, No. 1, 2008, pp. 65-73.

[16] J.O. Finckenauer, "Problems of Definition: What Is Organized Crime?" Trends in Organized Crime, Vol. 8, No. 3, 2005, pp. 63-83. doi:10.1007/s12117-005-1038-4

[17] V. Ruggiero, "Organized Crime: Between the Informal and the Formal Economy," Global Consortium on Security Transformation, Working Paper Series, No. 4, July 2010.

[18] S. Ciotti, "The Dangerous and Toxic Waste Management and the Organized Crime: From Exploitation to International Health Emergency," Presentation, St. John International University, Umea, Sweden, 25-26 November 2008

[19] A. Szasz, "Corporations, Organized Crime, and the Disposal of Hazardous Waste: An Examination of the Making of a Criminogenic Regulatory Structure," Criminology, Vol. 24, 1986, pp. 1-27. doi:10.1111/j.1745-9125.1986.tb00374.x

[20] L. Greyl, S. Vegni, M. Natalicchio, S. Cure and J. Ferretti, "The Waste Crisis in Campania, Italy," A Case Study, Prepared for the Ecological Economic for and by NGOs (CEECEC), May 2010, Accessed September 2011. http://www.CEECEC.Net/case-studies/waste-crisis-in-Ca mpania-italy/

[21] M. Massari and P. Monzini, "Dirty Businesses in Italy: A Case-Study of Illegal Trafficking in Hazardous Waste," Global Crime, Vol. 6, No. 3-4, 2004, pp. 285-304. doi:10.1080/17440570500273416

[22] C. Gibbs, E. F. McGarrell and M. Axelrod, "Transnational White-Collar Crime and Risk: Lessons from the Global Trade in Electronic Waste," Criminology \& Public Policy, Vol. 9, No. 3, 2010, pp. 543-560. doi:10.1111/j.1745-9133.2010.00649.x

[23] R. Tillman, "Making the Rules and Breaking the Rules: The Political Origins of Corporate Corruption in the New Economy," Crime Law Soc Change, Vol. 51, 2009, pp. 73-86. doi:10.1007/s10611-008-9150-4

[24] W. J. Sutherland and H. J. Woodroof, "The Need for
Environmental Horizon Scanning," Trends in Ecology \& Evolution, Vol. 24, No. 10, 2009, pp. 523-527. doi:10.1016/i.tree.2009.04.008

[25] W. J. Sutherland, M. Clout, I. M. Cŏté, P. Daszak, M. H. Depledge, L. Fellman, E. Fleishman, R. Garthwaite, D. W. Gibbons, J. De Lurio, A. J. Impey, F. Lickorish, D. Lindenmayer, J. Madgwick, C. Margerison, T. Maynard, L. S. Peck, J. Pretty, S. Prior, K. H. Redford, J. P. W. Scharlemann, M. Spalding and R. Watkinson, "A Horizon Scan of Global Conservation Issues for 2010," Trends in Ecology and Evolution, Vol. 25, No. 1, 2010, pp. 1-7. doi:10.1016/j.tree.2009.10.003

[26] R. White and D. Heckenberg, "Environmental Horizon Scanning and Criminological Theory and Practice," European Journal on Criminal Policy and Research, Published on line 12 February 2011, Accessed on 21 March, 2011.

http://www.springerlink.com/content/k846m4n7p183422 7/fulltext.pdf

[27] D. Thomas, “\$5840 Fine for Stinking Wodonga Stockpile," The Border Mail, 22 July 2010, Accessed October 2010.

http://www.bordermail.com.au/news/local/news/general/5 840-fine-for-stinking-wodonga-stockpile/1892358.aspx

[28] A. Salleh, "Clock Ticking on Growing Toxic Waste Pile," ABC Science, 30 June 2010, Accessed October 2010 .

http://www.abc.net.au/science/articles/2010/06/30/29402 70.htm

[29] S. Parnell, "Toxic Waste Stockpile Spurs Push to Export It to Europe," The Australian, 19 February 2009.

[30] Environmental Defenders Office WA Inc, "Waste Management in Western Australia: Current Law and Practice and Recommendations for Reform," Environmental Defenders Office WA Inc, August 2007, Accessed October 2010 .

http://www.edowa.org.au/submissions/EDOwastemanage mentreport.pdf

[31] Environmental Protection Authority SA, "EPA Guideline: Waste Tyres," EPA 2010, South Australia, Updated September 2010.

[32] S. Wainwright, "Toxic Fire Exposes Working Class Community," Green Left Weekly, 15 May 2010. Accessed October 2010.

http://www.greenleft.org.au/taxonomy/term/1205>

[33] J. Angel, "Submission to Standing Committee on The Environment, Communications and the Arts on Management of Australia's Waste Streams and the Drink Container Recycling Bill 2008," Total Environment Centre Inc, May 2008, Accessed October 2010.

http://www.aph.gov.au/senate/committee/eca_ctte/aust_w aste_streams/submissions/sub067.pdf 